\title{
PREDICTORS OF PRESSURE ULCERS IN PATIENTS WITH SPINAL CORD INJURIES
}

Sasa Milicevic ${ }^{1}$, Zoran Bukumiric ${ }^{2}$, Aleksandra Karadzov Nikolic ${ }^{3}$, Rade Babovic ${ }^{1}$, Aleksandra Sekulic ${ }^{1}$, Srbislav Stevanovic ${ }^{1}$, Slobodan Jankovic ${ }^{4}$

${ }^{1}$ Clinic for Rehabilitation "Dr M. Zotović", Sokobanjska 13, Belgrade

${ }^{2}$ Medical Faculty in Pristina, Institute of Medical Statistics and Informatics, Kosovska Mitrovica

${ }^{3}$ Institute of Rheumatology, Resavska 69, Belgrade

${ }^{4}$ Medical Faculty in Kragujevac, Institute of Pharmacology, Kragujevac

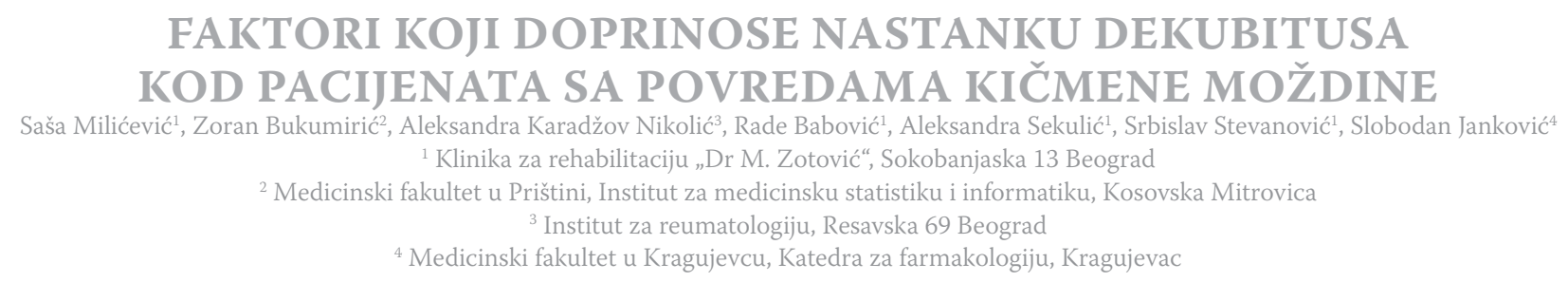

Received / Primljen: 04. 03. 2012

Accepted / Prihvaćen: 21. 03. 2012.

\section{ABSTRACT}

Introduction: Pressure ulcers (PUs) are often secondary complications in spinal cord injury (SCI) patients.

Purpose: To investigate the presence and possible factors associated with pressure ulcers in SCI patients undergoing acute and functional rehabilitation.

Methods: This was a retrospective study of 453 patients with SCI treated at the Clinic for Rehabilitation " $\mathrm{Dr} M$. Zotovic", Belgrade, Serbia, between January 2000 and December 2009. Factors that were tested for their influence on pressure ulcers in spinal cord injury patients included age, sex, mechanism of injury, neurological level of injury, completeness of injury, spasticity and length of stay. The presence and location of pressure ulcers were recorded on admission, during acute and functional rehabilitation and at discharge. The level of statistical significance in our study was set to 0.05.

Results: The study included 453 patients: 383 (84.5\%) did not have a pressure ulcer during rehabilitation, and $70(15.5 \%)$ patients had a pressure ulcer during rehabilitation. Of the total number of patients, 333 (73.5\%) were male, and 120 (26.5\%) were female. The average age of patients enrolled in the study was $51.8 \pm 17.2$ years. In a multiple logistic regression model, one statistically significant predictor of pressure ulcers during rehabilitation was pressure ulcer before rehabilitation $(B=1420, p<0.001)$, with an odds ratio $(O R)=4.1$. This result shows that patients who had pressure ulcers on admission are 4 times more likely to regain pressure ulcers during rehabilitation after controlling for all of the factors in the model. Another statistically significant predictor of pressure ulcers during rehabilitation was FIM score on admission ( $B=-0036, p=0.015$ ).

Conclusion: The prevention of pressure ulcers in acute and functional rehabilitation increases functional outcomes in patients with SCI.

Keywords: spinal cord injury, pressure ulcer, predictors, rehabilitation

\section{SAŽETAK}

Uvod: dekubitalni ulkus je česta komplikacije kod pacijenata sa povredom kičmene moždine.

Cilj: utvrditi učestalost i faktore rizika dekubitalnih ulkusa kod pacijenata sa povedom kičmene moždine u toku rehabilitacije.

Materijal i metode: ovaj rad predstavlja retrospektivnu studiju koja je obuhvatila 453 pacijenta sa povredom kičmene moždine koji su rehabilitovani u Klinic za rehabilitaciju Dr M. Zotović, Beograd, Srbija u periodu od Januara 2000. do Decembra 2009. godine. Faktori rizika dekubitlanih ulkusa kod pacijenata sa povredom kičmene moždine koji su ispitivani u ovoj studiji su: starost, pol, način povređivanja, neurološki nivo povrede, kmpletnost lezije, spasticitet $i$ dužina boravka. Postojanje lokalizacija dekubitalnih ulkusa je bila registrovana na prijemu, $u$ toku rehabilitacije i na otpustu. Nivo statističke značajnosti je testiran na nivou od 0.05 .

Rezultati: u studiju je uključeno 453 pacijenata od kojih 383 (84.5\%) nije imalo dekubitalni ulkus u toku rehabilitacije $i 70$ (15.5\%) pacijenata sa dekubitalnim ulkusom u toku rehabilitacije. Od ukupnog broja pacijenata 333 (73.5\%) na bilo muškog i 120 (26.5\%) je bilo ženskog pola. Prosečna starost pacijenata koji su uključeni u studiju je bila $51.8 \pm 17.2$ godina. U multiplo regresionom modelu statiskički značajan prediktor dekubitalnog ulkusa u toku rehabiltiacije je bio postojanje ulkusa pre rehabilitacije ( $B=1420, p<0.001)$, sa odnosom šansi OR=4.1. Ovo na pokazuje da pacijenti koji su imali dekubitalni ulkus na prijemu imaju četiri puta veću šansu da ponovo dobiju ulkus u toku rehabilitacije. Takođe statistički značajan predikto dekubitlanih ulkusa u toku rehabilitacije je bio FIM skot na prijemu ( $B=-0036, p<0.015)$.

Zaključak: prevencija dekubitlanih ulkusa skraćuje vreme rehabilitacije i povećava funkcionalni oporavak kod pacijenata sa povredom kičmene moždine.

Ključne reči: povrede kičmene moždine, dekubitalni ulkusi, prediktori, rehabilitacija 


\section{INTRODUCTION}

A pressure ulcer (PU) is defined as a localised area of cellular necrosis and vascular destruction created as a result of prolonged exposure to pressure, shearing or friction (1). Pressure ulcers occur at a high incidence in spinal cord injury (SCI) patients (2). The epidemiology of PU varies considerably in patients with SCI by clinical setting, with incidence rates ranging from 0.4 to $38 \%$ in acute care, 2.2 to $23.9 \%$ in long-term care, and 0 to $17 \%$ in home care $(3,4)$. The annual incidence and prevalence rates of PUs range from 20 to $31 \%$ and 10.2 to $30 \%$, respectively (4). Yarkony and Heinemann reported a prevalence of $8 \%$ during initial rehabilitation, $9 \%$ during the 2 -year follow-up after rehabilitation, and $32 \% 20$ years after rehabilitation (5). In a previous study, over two hundred risk factors for the development of pressure ulcers were described. The most important factors are inactivity, incontinence, neurological level of injury, completeness of injury, autonomic dysreflexia, secondary complications, such as spasticity, and nutritional, physical and socioeconomic status $(5,6)$. Secondary conditions, such as smoking, age and some conditions or diseases, such as gastrointestinal, cardiopulmonary and renal diseases, diabetes mellitus, reduced cognitive abilities, malnutrition, anaemia, hypoalbuminaemia $(<3.4 \mathrm{~g} /$ dl) and low haemoglobin $(<12 \mathrm{~g} / \mathrm{dl})(8)$, play an important role in the development of pressure ulcers. PUs may have a significant impact on patients with SCI. PUs significantly decrease the quality of life, and if the PUs cannot be treated conservatively, they may lead to interrupted rehabilitation, extended length of stay, increased cost of care and increased hospital readmission $(9,10)$.

The first aim of our study was to investigate occurrence of pressure ulcers in patients with spinal cord injuries. The second aim of this study was to identify factors that influenced the development of PUs during rehabilitation.

\section{MATERIALS AND METHODS}

This was a retrospective study of 453 patients with spinal cord injury treated at the Clinic for Rehabilitation "Dr M. Zotovic", Belgrade, Serbia, between January 2000 and December 2009. For all of the patients, a detailed hospital history with respect to sex, age, mode of trauma, and clinical and radiological examination was obtained. The influential factors of pressure ulcers in SCI patients included age, gender, mechanism of injury, pressure ulcer in the acute phase of rehabilitation, neurological level of injury, completeness of injury, spasticity, FIM score on admission and length of stay. The criteria for conducting the study were the following: $1^{\text {st }}$, all of the patients were diagnosed with spinal cord injuries; and $2^{\text {nd }}$, all of the patients had spinal cord injury that showed signs of neurological lesions of the spinal cord. The criteria for exclusion from the study were the following: $1^{\text {st }}$, any type of underlying deterioration that resulted in termination of rehabilitation; $2^{\text {nd }}$, patients younger than 18 years; and $3^{\text {rd }}$, all patients with an injury below the $\mathrm{L}_{1}$ level of the spinal cord.

The presence and location of pressure ulcers were recorded on admission, during acute and functional rehabilitation and at discharge. During hospitalisation, the patients were assessed by tests aimed at measuring the degree of their functional recovery and the presence of neurological sequelae after spinal injury: (1) the FIM test (Functional Independence Measure) was used to assess the functional status of patients, (2) the ASIA scale (American Spinal Injury Association impairment scale) was used to assess motor and sensory levels and completeness of the injury and (3) the MAS score (Modified Ashworth Score) was used to determine the level of spasticity $(11,12,13,14)$.

Statistical analysis: For the analysis of primary data, descriptive statistical methods and hypothesis-testing methods were used. Among the descriptive statistical methods, we used central tendencies (arithmetic mean and median), measures of variability (standard deviation) and relative numbers. To test the hypothesis of the difference in frequency, a Chi-squared test was used. A t-test of exact probability was used for testing hypotheses of the difference in arithmetic means. The relationships between binary outcomes and potential predictors were analysed by logistic regression. The level of statistical significance in our study was set to 0.05 .

\section{RESULTS}

The study included 453 patients, of whom 383 (84.5\%) did not have a pressure ulcer and 70 (15.5\%) had a pressure ulcer during rehabilitation.

The average age of patients in the study was $51.8 \pm 17.2$ years. The youngest patient was 19, and the oldest was 91 years old. The average age of patients without PUs was 52.1 \pm 17 years, while for patients with PUs, the average age was $50.2 \pm 14.6$ years. Between the two groups, there was no significant difference $(\mathrm{p}=0382)$.

Of the total number of patients, 333 (73.5\%) were male, and $120(26.5 \%)$ were female. The gender frequency between patients with or without PUs was statistically insignificant $(\mathrm{p}=0297)$.

Of the total number of patients, 292 (64.5\%) had traumatic and 161 (35.5\%) had non-traumatic spinal cord injury. Patients with pressure ulcers had significantly more traumatic injuries compared with patients without pressure ulcers $(77.1 \%$ vs. $62.1 \%$, respectively) $(\mathrm{p}=0.016)$.

Of the total number of patients, 253 (55.8\%) had an incomplete lesion, and 200 (44.2\%) had a complete spinal cord lesion. Patients with pressure ulcers had significantly more complete lesions than patients without pressure ulcers $(58.6 \%$ vs. $41.5 \%$, respectively) ( $p=0.008)$.

At admission, in relation to the neurological level of injury, injuries of the thoracic spinal cord (43.9\%) were most frequent, followed by cervical injuries (40.8\%) and lumbar 


\begin{tabular}{|c|c|c|c|}
\hline & $\begin{array}{l}\text { Without pressure ulcer } \\
(\mathrm{n}=383)\end{array}$ & $\begin{array}{l}\text { With pressure ulcer } \\
(\mathrm{n}=70)\end{array}$ & p \\
\hline Age, $\bar{x} \pm \mathrm{SD}$ & $52.1 \pm 17.6$ & $50.2 \pm 14.6$ & 0.382 \\
\hline $\begin{array}{l}\text { Gender, } \mathrm{n}(\%) \\
\text { male } \\
\text { female }\end{array}$ & $\begin{array}{l}278(72.6 \%) \\
105(27.4 \%)\end{array}$ & $\begin{array}{l}55(78.6 \%) \\
15(21.4 \%)\end{array}$ & 0.297 \\
\hline $\begin{array}{l}\text { Mode of trauma, } \mathrm{n}(\%) \\
\text { traumatic } \\
\text { non-traumatic }\end{array}$ & $\begin{array}{l}238(62.1 \%) \\
145(37.9 \%) \\
\end{array}$ & \begin{tabular}{|l}
$54(77.1 \%)$ \\
$16(22.9)$ \\
\end{tabular} & 0.016 \\
\hline $\begin{array}{l}\text { Completeness of lesion, } \mathrm{n}(\%) \\
\text { incomplete } \\
\text { complete }\end{array}$ & $\begin{array}{l}224(58.5 \%) \\
159(41.5 \%) \\
\end{array}$ & $\begin{array}{l}29(41.4 \%) \\
41(58.6 \%) \\
\end{array}$ & 0.008 \\
\hline $\begin{array}{l}\text { Level of injury, n (\%) } \\
\text { cervical } \\
\text { thoracic } \\
\text { lumbar } \\
\end{array}$ & $\begin{array}{l}158(41.3 \%) \\
163(42.6 \%) \\
62(16.2 \%) \\
\end{array}$ & $\begin{array}{l}27(38.6 \%) \\
36(51.4 \%) \\
7(10.0 \%) \\
\end{array}$ & 0.266 \\
\hline Spasticity on admission, $\mathrm{n}(\%)$ & $105(27.4 \%)$ & $17(24.3 \%)$ & 0.587 \\
\hline Pressure ulcer in acute phase of rehabilitation, n (\%) & $20(5.2 \%)$ & $15(21.4 \%)$ & $<0.001$ \\
\hline FIM score on admission, $\bar{x} \pm \mathrm{SD}$ & $80.9 \pm 11.9$ & $75.3 \pm 10.3$ & $<0.001$ \\
\hline
\end{tabular}

Table 1. Characteristics of patients with spinal cord injury

injuries (15.2\%). In patients without pressure ulcers, thoracic spine injuries were the most common (42.6\%), followed by injuries of the cervical spine (41.3\%) and lumbar spine (16.2\%). In patients with pressure ulcers, thoracic spinal cord injuries occurred in $51.4 \%$ of patients, followed by cervical spine (38.6\%) and lumbar spine injuries (10.0\%). The incidence of the neurological level of injury between patients with or without PUs was statistically insignificant ( $\mathrm{p}=0266)$.

At admission, $27.4 \%$ of patients without ulcers had spasticity, and $24.3 \%$ of patients had bedsores, which was not a statistically significant difference $(\mathrm{p}=0587)$.

A total of $35(7.7 \%)$ patients had pressure ulcers at admission. Patients with pressure ulcers during rehabilitation were significantly more likely to have had pressure ulcers at admission than patients without pressure ulcers $(21.4 \%$ vs. $5.2 \%$, respectively) ( $<<0.001)$. Of the total number of patients with pressure ulcers, 54 (77.1\%) had a pressure ulcer on the sacrum, $8(11.4 \%)$ on the trochanter, $6(8.5 \%)$ on the heels, and two $(2.8 \%)$ on the ischium.

The average FIM score at admission for all patients was $80.1 \pm 11.9$. The average FIM score in patients who had no pressure ulcers was $80.9 \pm 11.9$, while the average FIM in patients with pressure ulcers was $75.3 \pm 10.3$, which was a statistically significant difference $(\mathrm{p}<0.001)$.

The average length of stay for all patients was $153.1 \pm$ 92.9 days. The average length of stay for patients without pressure ulcers was $149.9 \pm 91.4$ days, and $170.6 \pm 100.0$ days for patients with pressure ulcers, which is not a statistically significant difference ( $\mathrm{p}=0.085$ ).

A multiple logistic regression model was constructed by including predictors that were statistically significant in simple regression models at a 0.05 level of significance. The model also included the neurological level of the lesion, which was expected to be a significant predictor of pressure ulcers based on previous research. The results of the multiple logistic regression analyses are shown in Table 2.

The model contained five predictors listed in Table 1, which were compared in 453 patients. The entire model (all of the predictors) was statistically significant (Chisquare $=30.260, \mathrm{DF}=5, \mathrm{p}<0.001)$.

In the multiple logistic regression model, a statistically significant predictor of pressure ulcers during rehabilitation was pressure ulcers before rehabilitation $(B=1420, p$ $<0.001)$, with an odds ratio $(\mathrm{OR})=4.1$. This result shows

\begin{tabular}{|c|c|c|c|c|c|}
\hline \multirow{2}{*}{ The independent variable } & \multirow{2}{*}{ B } & \multirow{2}{*}{$\mathbf{p}$} & \multirow{2}{*}{ OR } & \multicolumn{2}{|c|}{$\mathbf{9 5} \%$ confidence interval } \\
\hline & & & & Lower limit & Upper limit \\
\hline Mode of trauma & -0.209 & 0.536 & 0.8 & 0.4 & 1.6 \\
\hline Completeness of lesion & 0.302 & 0.304 & 1.4 & 0.8 & 2.4 \\
\hline Level of injury & 0.082 & 0.709 & 1.1 & 0.7 & 1.7 \\
\hline Pressure ulcer in acute phase of rehabilitation & 1.420 & $<0.001$ & 4.1 & 1.9 & 8.7 \\
\hline FIM score on admission & -0.036 & 0.015 & 0.9 & 0.94 & 0.99 \\
\hline
\end{tabular}

Table 2. Multiple logistic regression with pressure ulcers during rehabilitation as a dependent variable. 
that patients who had pressure ulcers at admission are 4 times more likely to regain pressure ulcers during rehabilitation after controlling for all of the factors in the model. Another statistically significant predictor of pressure ulcers during rehabilitation was FIM score at admission (B $=-0036, \mathrm{p}=0.015)$.

\section{DISCUSION}

In our study, PU was present in $15.5 \%$ of the sample during a 10 -year study period. Garber and Rintala found PU in 36\% of their mail-based survey and 39\% of 553 veterans in the Houston VA SCI registry over a 3-year period (15). Age of SCI onset, SCI duration, presence of depression, and faecal/urinary incontinence showed no significant association with the presence or development of PUs. Similar to the findings of Salzberg et al., Mawson et al. and Rodriguez and Garber found diabetes mellitus, smoking, and depression to influence PU development $(15,16)$. Many risk factors are associated with the development of pressure ulcers in SCI patients. All of these factors were associated with PUs; it is not known whether they increase the risk of PU development or are the result of PUs.

In our study, the most commonly reported location of pressure ulcers was at the sacrum (77.1\%), followed by the trochanter $(11.4 \%)$, ischium (8.5\%) and heel (2.8\%). In other studies, the sacrum was the most commonly reported location (39-52\%), followed by the ischium (8-59\%) and heel (13-31\%) (17).

Using a simple logistic regression, we found that statistically significant predictors of PUs were mode of trauma, completeness of injury, PUs in acute phase of rehabilitation and FIM score at admission. Age, gender, duration of rehabilitation and neurological level of injury were statistically insignificant for the development of PUs during functional rehabilitation. In our study, the neurological level of injury was statistically insignificant as a PU predictor. Therefore, PUs occur more frequently in paraplegic patients than tetraplegic patients. Previous studies have reported similar findings $(7,18,19)$.

Using the multiple logistic regression model, we found that statistically significant predictors of PUs were pressure ulcers in the acute phase of rehabilitation and FIM score at admission. A pressure ulcer in the acute phase of rehabilitation was a strong predictor of PUs during functional rehabilitation, with $\mathrm{OR}=4.1$. This result shows that patients who had a pressure ulcer at admission had a fourtime greater probability of regaining a pressure ulcer during functional rehabilitation. Similar findings have been reported in a previous study. Verschueren et al. showed that a pressure ulcer in the acute phase of rehabilitation was a strong predictor of PUs, with $\mathrm{OR}=5.1$ (19). In our study, FIM score at admission was a strong predictor for the development of pressure ulcers. This finding is in accordance with previous studies (19). This association is because increased immobilisation (due to absent motor function) promotes the development of PUs.

\section{CONCLUSION}

Significant risk factors for developing pressure ulcers during acute and functional rehabilitation are pressure ulcers during the acute phase of rehabilitation and FIM score at admission. Because PUs have a significant impact on rehabilitation and functional outcomes in patients with SCI, it is necessary to construct a predictive model for the development of pressure ulcers. Developing a model for the prediction of PUs allows us to recognise risk categories of patients and react in terms of prevention or treatment of PUs. This study emphasises the need to continue educating patients with SCI about the importance of effective regular healthy skin care in preventing PU development.

\section{REFERENCES}

1. Correa GI, Fuentes M, Gonzalez X, Cumsille F, Pin JL, J Finkelstein J. Predictive factors for pressure ulcers in the ambulatory stage of spinal cord injury patients. Spinal Cord 2006; 44: 734-739.

2. Consortium for Spinal Cord Medicine Clinical Practice Guidelines. Pressure ulcer prevention and treatment following spinal cord injury: a clinical practice guideline for health-care professionals. J Spinal cord med 2001; 24 (Suppl 1): S40-S101.

3. Saladin LK, Krause JS. Pressure ulcer prevalence and barriers to treatment after spinal cord injury: comparisons of four groups based on race-ethnicity. Neuro Rehabilitation 2009; 24: 57-66.

4. Rabadi MH, Vincent AS. Do vascular risk factors contribute to the prevalence of pressure ulcer in veterans with spinal cord injury? J.Spinal Cord Med 2011; 34: 46-51.

5. Yarkony GM, Heinemann AW, Stover SL, DeLisa JA, Whiteneck GG (eds.). Spinal cord injury: clinical outcomes from the model systems. Aspen Publishing; 1995. p. 100-19.

6. Byrne DW, Salzberg CA. Major risk factors for pressure ulcers in the spinal cord disabled: a literature review. Spinal Cord 1996; 34: 255-263.

7. Chen Y, Devivo MJ, Jackson AB: Pressure ulcer prevalence in people with spinal cord injury: age-periodduration effects. Arch Phys Med Rehabil 2005; 86: 1208-1213,.

8. Smith BM, Guihan M, LaVela SL, Garber SL. Factors predicting pressure ulcers in veterans with spinal cord injuries. Am J Phys Med Rehabil 2008; 87: 750-7.

9. Krause JS. Skin sores after spinal cord injury: relationship to life adjustment. Spinal Cord 1998; 36: 51-6.

10. National Pressure Ulcer Advisory Panel. Pressure ulcer stages revised by NPUAP. 2007 [accessed 2010 Jun 6]. Available from: http://www.npuap.org/pr2.htm.

11. Uniform Data System for Medical Rehabilitation. Guide for the Uniform Data Set for Medical Rehabilitation (including the FIMt Instrument), version 5.1. State University of New York: Buffalo 1997. 
12. The National Spinal Cord Injury Statistical Center, Birmingham, AL. Spinal Cord Injury: facts and figures at a glance; 2010 Available from: https://www.nscisc.uab. edu Accessed January 29, 2011.

13. American Spinal Injury Association (ASIA). International standards for neurological classification of spinal cord injury. Chicago: ASIA; 2002.

14. Bohannon RW, Smith MB. Interrater reliability of a modified Ashworth scale of muscle spasticity. Phys Ther 1987; 67: 206-207.

15. Garber SL, Rintala DH, Hart KA, Fuhrer MJ. Pressure ulcer risk in spinal cord injury: predictors of ulcer status over 3 years. Arch Phys Med Rehabil 2000; 81: 465-471.

16. Salzberg CA, Byrne DW, Cayten CG, Kabir R, van Nieuwerburgh P, Viehbeck $M$ et al. Predicting pressure ulcers during initial hospitalization for acute spinal cord injury. Wounds 1999; 11: 45-57.

17. Mohamm RR, Soheil S, Moghadam MMPH, P.T, Vaccaro RA, Rahimi-Movaghar V. Factors associated with pressure ulcers in patients with complete or sensoryonly preserved spinal cord injury: is there any difference between traumatic and nontraumatic causes. J Neurosurg Spine 2009; 11: 438-444.

18. New PW, Rawicki HB, Bailey MJ. Nontraumatic spinal cord injury rehabilitation: pressure ulcer patterns, prediction and impact. Arch Phys Med Rehabil 2004; 85: 87-93. 19. Verschueren JHM, Post MWM, De Groot S, Van der Woude LHV, Van Asbeck FWA, Rol M. Occurrence and predictors of pressure ulcers during primary inpatient spinal cord injury rehabilitation. Spinal Cord 2011; 49: 106-112.

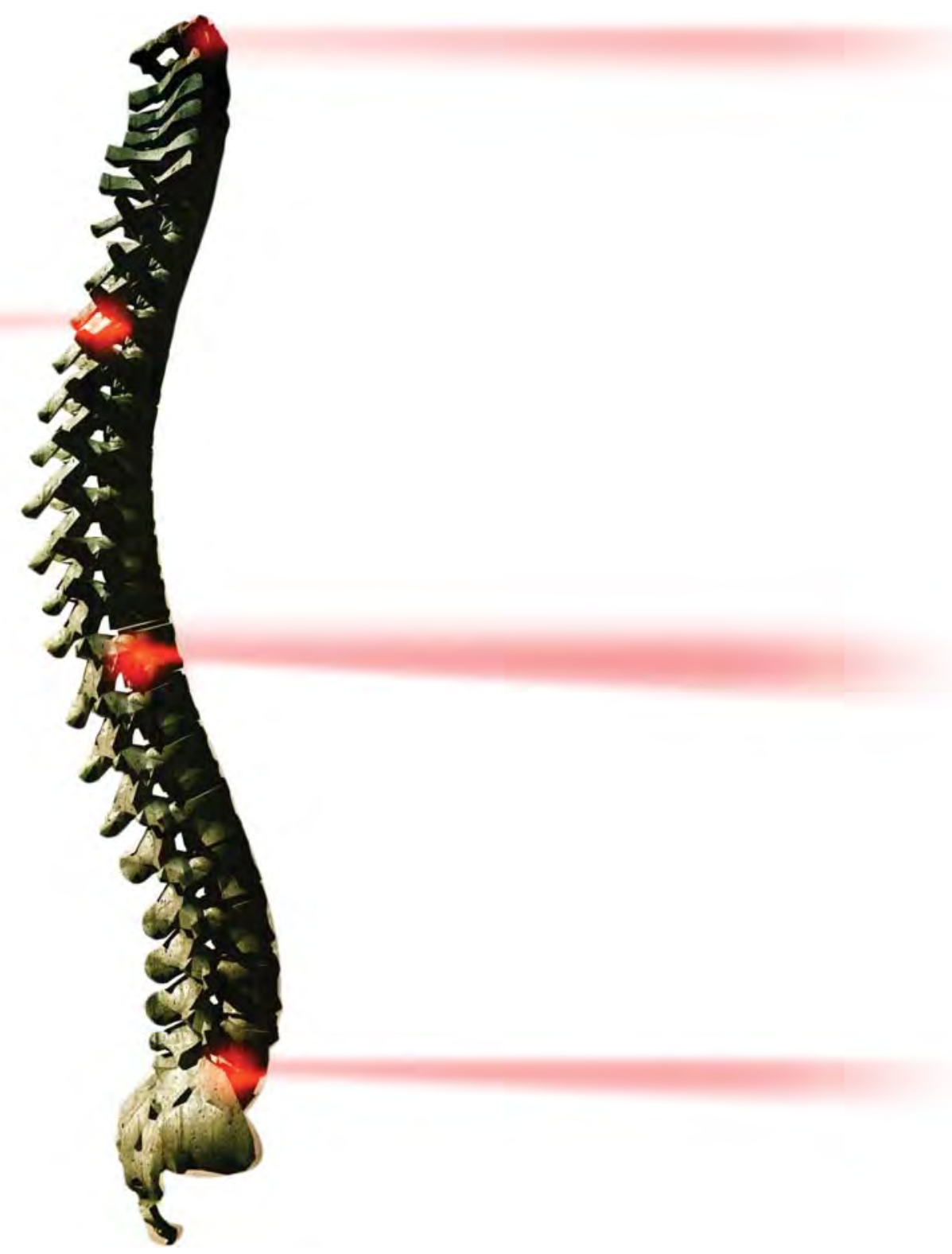

